\title{
TECHNOLOGY ACCEPTANCE MODEL AND TRUST IN EXPLAINING CUSTOMER INTENTION TO USE INTERNET BANKING
}

\author{
Putra Agus Adi Sana*, Suprapti Ni Wayan Sri, Yasa Ni Nyoman Kerti, \\ Sukaatmadja I Putu Gde \\ Faculty of Economics and Business, University of Udayana, Bali, Indonesia \\ ${ }^{\star}$ E-mail: agus.adi.jbm@gmail.com
}

\begin{abstract}
The purpose of this study is to explain the effect of the Application of Technology Acceptance Model and Trust in Explaining Customer Intention to Use Bank Negara Indonesia (BNI) Internet Banking in Denpasar. The sampling technique in this study was purposive sampling because the population was not known with certainty. The indicators in this study were 20 indicators, so the total respondents were 200 people. The criteria for determining the sample are BNI customers who have never used the internet banking feature and have at least graduated from high school/equivalent. The data collection technique used in this study was questionnaire techniques. The data obtained were analyzed using SEM (Strucutral Equation Modeling) analysis. The results shows that perceived ease of use has a positive and significant effect on perceived usefulness BNI internet banking. Perceived ease of use has a positive and significant effect on attitude towards use BNI internet banking. Perceived usefulness has a positive and significant effect on attitude towards use BNI internet banking. Attitude towards use has a positive and significant effect on intention to use BNI internet banking. Perceived usefulness has a positive and significant effect on intention to use BNI internet banking. Perceived ease of use has a positive and significant effect on intention to use BNI internet banking. Trust has a positive and significant effect on attitude towards use $\mathrm{BNI}$ internet banking. Likewise, trust has a positive and significant effect on intention to use BNI internet banking.
\end{abstract}

\section{KEY WORDS}

Perceived ease of use, perceived usefulness, attitude towards use, intention to use, trust, TAM, Bank Negara Indonesia.

The development of information technology (IT) has an impact on the ease in which people move. Coupled with the development of new IT products such as laptops, tablets and mobile phones, it's easy to communicate on a mobile basis. The internet is one of the features of IT products that can access various information quickly and easily. In many service industries, technology dramatically changes the service process which once required many employees to interact with customers. Now technology-based systems help service processes and interactions with customers.

The Banking Institution is a service company, continuing to innovate to face competition with other financial institutions. Banking Institutions utilize the advances in information technology in their operations. Some banking service features that use IT advancements are phone banking, SMS banking, and internet banking.

Internet banking is a banking service facility that is accessed using IT products that are connected to the internet network. Internet banking makes it easy for customers to carry out banking transactions whether financial or non-financial transactions such as fund transfers, balance information, account transfers, exchange rate information, credit card, telephone, handphone and electricity bill payments, purchase transactions such as top-up credit and Flight Tickets (www.bi.go.id, 2012).

The attitude model used to measure attitudes towards technology applied to previous research is the TAM (Technology Acceptance Model) such as in South Korea with e-learning objects (Park, 2009), in Malaysia with internet banking objects (Raman, 2011), and in Kentucky America about the Word Wide Web. 
TAM is a model built to analyze and understand the factors that influence the acceptance of the use of computer technology put forward by Fred Davis in 1986 which is the development of TRA developed by Fishbein and Ajzen (Medyawati et al., 2011). The TAM model by Fred Davis consists of four variables perceptions of ease of use, perceived benefit, attitude to use, and intention to use.

Trust is one of the variables that influences the customer's attitude and intention to use internet banking. Research on the influence of the variable trust in attitude variables to use has been carried out as in the study by Al-Somali et al. who took up research in Saudi Arabia, showed that trust has a positive and significant influence on the attitude of internet banking users (Tjini and Baridwan, 2013). This research is supported by similar research in Malaysia by Al-Ajam and Nor (2013), and research in London by Alsajjan and Dennis (2006).

In some previous studies, the low internet banking revenue was caused by a lack of trust from customers in the internet banking application. In the study by Alsajjan and Dennis (2006) in his research in London it was stated that the influence of online banking trust on intention to use was clearly seen. Other research in Nigeria by Ayo et al. (2010) found similar results, namely trust in a positive and significant effect on the intention to use e-banking. In another study in Nigeria it was found that there was a positive and significant influence on attitudes to use (Akinyemi et al., 2013). Research by Mohan et al. (2013) in Malaysia found different results that trust does not have a positive and significant influence on intention to use. The results of the study of Mohan et al. supported by Rahmawaty's (2013) research conducted in Indonesia.

The phenomenon of low use of internet banking applications can be seen in use at Bank Negara Indonesia (BNI). BNI is one of the leading banks in Indonesia. Ever since 2007 $\mathrm{BNI}$ has had internet banking facilities. In BNI, transactions through electronic facilities continue to experience growth. The number of BNI e-Banking users is around 9 million Debit Card customers, 1.56 million BNI PhonePlus, 618,000 BNI Internet Banking users, and 3.25 million SMS Banking users. The achievement of transaction volume until August 2012 for BNI Phone Banking reached Rp. 448.96 billion. BNI Internet Banking reached Rp. 15.96 trillion, and BNI SMS Banking reached Rp. 6.86 trillion (bni.co.id, 2013). Based on this data, it is known that the adoption of the use of BNI Bank's bank facilities is the slowest compared to other BNI facilities.

Therefore, the purpose of this study is the behavior intention of customers to use internet banking services by focusing on users' perceptions of ease of use, internet banking benefits, attitudes towards internet banking, and trust in internet banking in meeting their banking needs.

\section{LITERATURE REVIEW}

The banking industry is an industry that markets services as a product. In the service industry is one important factor in the success of its marketing. In supporting its services, the bank has several technology products that help service performance such as sms banking, phone banking and internet banking. Internet banking is one of the leading products of the banking industry. Internet banking is a system where individuals, businesses or customers have access to their accounts, transact or transfer money, pay bills, obtain information about bank accounts and utilize other banks through the internet (Mukhtar, 2015).

The model most often used to measure IT acceptance is the Technology Acceptance Model (TAM). This model was first put forward by Davis based on the Theory of Reasoned Action (TRA) by Fishbien and Ajzen in 1975 in psychological research.

In Abeka (2012) TAM is defined as information theory which aims only to predict and explain user acceptance of information technology. This model discusses the reasons why users accept or reject certain parts of information technology. The basic concept of this theory is that perceptions of benefits, perceptions of ease of use and attitudes to use affect the user's intention to use information technology both directly and through mediating attitudes towards behavior, which leads to real use of the system. Perception of ease of use is the level at which someone believes that using the internet banking system will free up 
physical and mental effort. Benefit perception is a measure of individual subjective assessment of internet banking use in completing tasks. The attitude to use is defined as positive or negative feelings about the behavior of using internet banking. The intention to use is the tendency of behavior to continue using internet banking.

Trust is a belief in something and believes that in the end it will bring goodness or profit (Trisetyanto and Mudiantono, 2011). The banking industry is closely related to high levels of trust such as security and privacy issues (Yauzafzai et al. 2011).

\section{RESEARCH FRAMEWORK}

The use of information technology in the form of internet banking in supporting banking transactions is an important thing to study. The low use of internet banking will cause a low return on organizational investment in internet banking technology. The thinking framework of this study uses the TAM Davis model which uses four variables, namely perceptions of benefits, perceptions of ease of use, attitude to use, and intention to use added with confidence variables.

Based on this frame of mind, the conceptual framework of the research can be described, as follows.

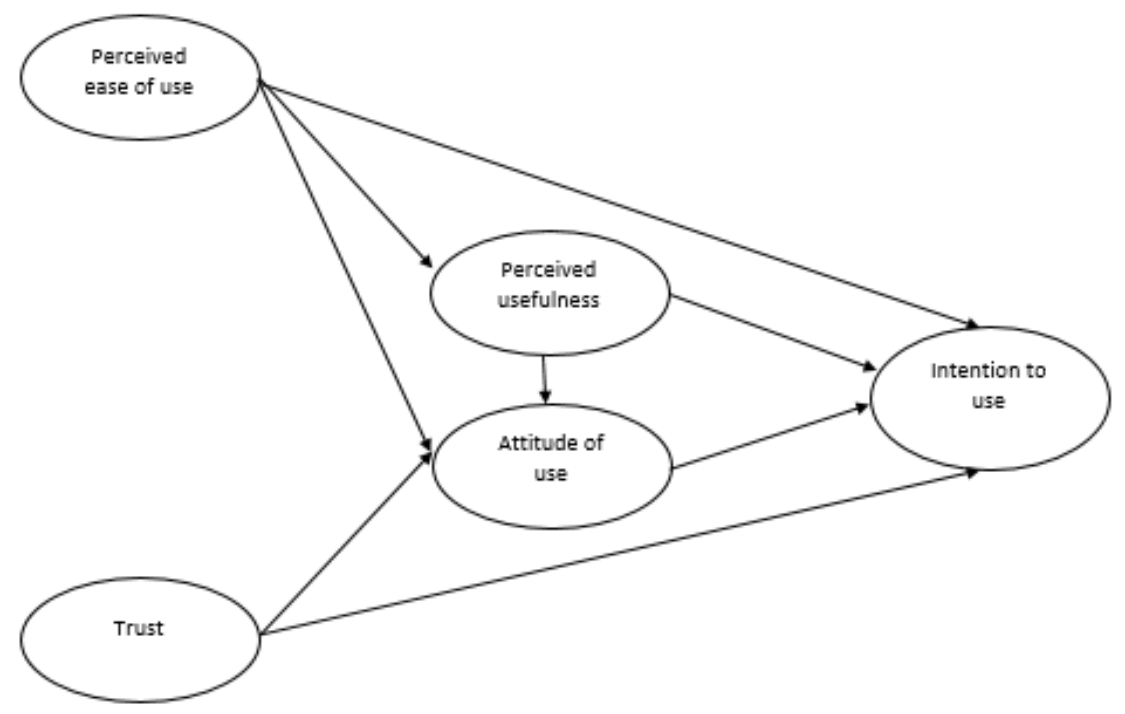

Figure 1 - Research Conceptual Framework

Based on the existing conceptual framework, the research hypotheses that can be compiled are as follows:

$\mathrm{H}_{1}$ Perceptions of ease of use have a positive and significant effect on the perceived benefits of Bank Negara Indonesia internet banking.

$\mathrm{H}_{2}$ Perception of ease of use has a positive and significant effect on the attitude to use Bank Negara Indonesia internet banking.

$\mathrm{H}_{3}$ Benefit perception has a positive and significant effect on the attitude to use Bank Negara Indonesia internet banking.

$\mathrm{H}_{4}$ The attitude to use has a positive and significant effect on the intention to use Bank BNI internet banking.

$\mathrm{H}_{5}$ Benefit perception has a positive and significant effect on the intention to use Bank Negara Indonesia internet banking.

$\mathrm{H}_{6}$ Perception of ease of use has a positive and significant effect with the intention to use Bank Negara Indonesia internet banking.

$\mathrm{H}_{7} \quad$ Trust has a positive and significant effect on the attitude to use Bank Negara Indonesia internet banking.

$\mathrm{H}_{8}$ Trust has a positive and significant effect on the intention to use Bank Negara Indonesia internet banking. 


\section{METHODS OF RESEARCH}

This research was conducted to determine the behavior of bank customers, especially $\mathrm{BNI}$ in Denpasar City. The behavior focused on the research is how strong the customer's intention to use internet banking is seen from the customer's perception of the benefits of internet banking, ease of using internet banking, trust in internet banking, and his attitude to using internet banking.

In this study there are two types of variable data to be examined, these variables are: 1) Exogenous Variables: perceptions of ease of use (X1) and trust (X2); and 2) Endogenous Variables: perception of benefits $(Y 1)$, attitude to use $(Y 2)$, and intention to use $(Y 3)$.

The population of this study is BNI customers in Denpasar who have never used internet banking with a minimum high school education level or equivalent and know about internet banking. The sample size of this study is 200 customers.

This study uses a questionnaire as an instrument in collecting data from respondents. The questionnaire contains several questions regarding the identity of the respondent and several statements about the variables in the study. Furthermore, the statements contained in the questionnaire are research indicators and measured using a Likert scale.

The instruments used were tested for validity and reliability in order to measure what they wanted to measure, and the consistency of the responses given by respondents. High and low validity shows the extent to which the data collected does not deviate from the description of the intended variable. Furthermore Sugiyono (2013: 178), argues that a variable is said to be valid if $r$ alpha> $r$ table. An instrument is said to be valid if the correlation $(r) \geq 0.30$. Instrument reliability testing of a variable is said to be reliable if $r$ alpha> $r$ table. An instrument is said to be reliable if the correlation value $(r)$ is above 0.60 or the Cronbach's Alpha value is $\geq 0.60$. Both tests used the SPSS version 22 computer program.

The causal relationship formulated in this study uses a complicated model, the variables in the model are recursively shaped. The form of a causal relationship like this requires an analytical tool that is able to explain the relationship, so that the inferential statistical method used in the data analysis of this research is Structural Equation Modeling (SEM).

\section{RESULTS OF STUDY}

Figure 2 shows all good goodness of fit index criteria which are indicated by X2-ChiSquare value of 180.425 and probability greater than 0.05 , which is 0.153 , GFI index with a value of 0.922 is good and AGFI index with a value of 0.899 is in the criteria marginal. Furthermore, the CMIN / DF index with a value of 1.114 , TLI with a value of 0.989 , CFI with a value of 0.991 and RMSEA with a value of 0.024 , all are in good criteria, TLI and CFI indices are strongly recommended, because this index is relatively insensitive to sample size and less affected by the complexity of the model (Ferdinand, 2002: 76), so that this model meets the standards of goodness of fit seen from the value of TLI (Tucker Lewis Index) and CFI (Comperative Fit Index).

Table 1 - Estimated Model Regression Weights

\begin{tabular}{|c|c|c|c|c|c|c|c|}
\hline \multicolumn{3}{|c|}{ Regression Weights } & \multirow{2}{*}{$\begin{array}{c}\text { Estimate Unstandardize } \\
.190\end{array}$} & \multirow{2}{*}{$\begin{array}{l}\text { S.E. } \\
.073\end{array}$} & \multirow{2}{*}{$\begin{array}{c}\text { Estimate } \\
\text { Standardize } \\
.219\end{array}$} & \multirow{2}{*}{$\begin{array}{l}\text { C.R. } \\
2.593\end{array}$} & \multirow{2}{*}{$\begin{array}{c}\mathrm{P} \\
.010\end{array}$} \\
\hline Benefits (y1) & $<--$ & Convenience $(x 1)$ & & & & & \\
\hline Attitude (y2) & $<---$ & Benefits (y1) & .427 & .078 & .487 & 5.483 & $* * *$ \\
\hline Attitude (y2) & $<---$ & Trust (x2) & .248 & .056 & .341 & 4.445 & $* * *$ \\
\hline Attitude (y2) & $<--$ & Convenience $(x 1)$ & .159 & .056 & .210 & 2.840 & .005 \\
\hline Intention (y3) & $<--$ & Convenience (x1) & .150 & .067 & .138 & 2.234 & .025 \\
\hline Intention (y3) & $<--$ & Attitude (y2) & .561 & .132 & .392 & 4.237 & $\star \star \star *$ \\
\hline Intention (y3) & $<---$ & Benefits (y1) & .513 & .105 & .409 & 4.882 & 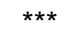 \\
\hline Intention (y3) & $<--$ & Trust (x2) & .225 & .070 & .216 & 3.212 & .001 \\
\hline
\end{tabular}

Source: Data processed, 2017. 


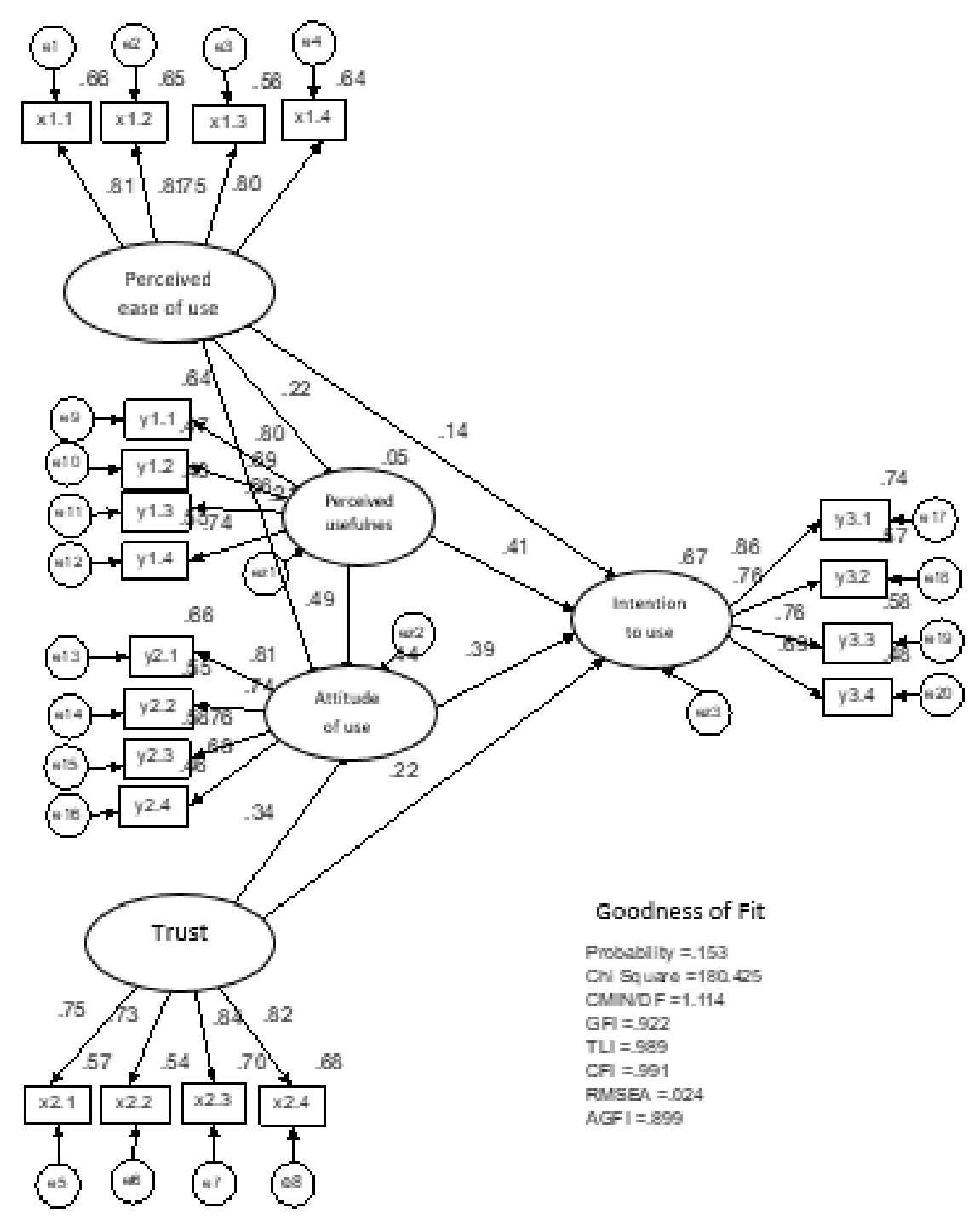

Figure 2 - Results of Estimated Structural Equation Models

\section{DISCUSSION OF RESULTS}

The estimation results of structural models as presented in Table 1 show that testing of this hypothesis produces a patharized direct effect value of 0.219 with a significance value (p) of 0.010. That is, that the construct of Perceived Ease of Use has a positive and significant effect on Perception of Benefits. These results are in line with several previous studies such as by Shroff et al. (2011) with the object e-portfolio system, research by Chang et al. (2011) in Taiwan, and in research by Sheikhi (2012) with the object of electronic banking research.

The estimation results of structural models as presented in Table 1 show that testing of this hypothesis produces a path coefficient (standarized direct effect) of 0.210 with a significance value $(p)$ of 0.005 . That is, that the construct of perceived usefulness has a positive and significant effect on attitudes to use. These results are in line with several previous studies such as the study in Kenya by Lule et al. (2012), in Iran by Sheikhi (2012), and Tan et al. (2012) in his research in Taiwan.

The estimation results of the structural model as presented in Table 1 show that the testing of this hypothesis yields a standarized direct effect of 0.487 with a significance value (p) of 0.000 . That is, that the construct of Benefit Perception has a positive and significant effect on Attitudes to Use. These results are in line with other studies in several countries 
such as Hong Kong (Cheng et al., 2006), Sudan (Tingari and Abdelraman, 2012), Taiwan (Tan et al., 2012), and Kenya (Njuguna et al., 2012).

The estimation results of the structural model as presented in Table 1 show that the testing of this hypothesis results in a standarized direct effect of 0.392 with a significance value (p) of 0,000 . That is, that the construct of the attitude to use has a positive and significant effect on the intention to use. This result is in line with previous research by Venkatesh and Bala (2008).

The estimation results of structural models as presented in Table 1 show that the testing of this hypothesis results in a standarized direct effect of 0.409 with a significance value $(p)$ of 0.000 . That is, that the construct of benefit perception has a positive and significant effect on intention to use. These results are in line with the research of Rigopoulos and Askounis (2007) and Jayasingh and Eze (2010) conducted in Greece and Malaysia.

The estimation results of the structural model as presented in Table 1 show that the testing of this hypothesis yields the value of the path coefficient (standarized direct effect) of 0.138 with a significance value $(p)$ of 0.025 . That is, that the construct of perceived ease of use has a positive and significant effect on intention to use. These results are in line with research by Al-maghrabi and Denis (Safeena et al., 2011) and Wang et al. (Mayasari et al., 2011).

The estimation results of the structural model as presented in Table 1 show that the testing of this hypothesis yields the path coefficient (standarized direct effect) of 0.341 with a significance value (p) of 0.000 . That is, that the construct of trust has a positive and significant effect on the attitude to use. This result is in line with other studies by Al-Ajam and Nor (2013) in Malaysia and significant and in London by Alsajjan and Dennis (2006).

The estimation results of structural models as presented in Table 1 show that the testing of this hypothesis yields a patharized direct effect value of 0.216 with a significance value (p) of 0.001 . That is, that the construct of trust has a positive and significant effect on the intention to use. This result is in line with previous research by Mohan et al. (2013) in Malaysia, and Rahmawaty (2013) conducted in Indonesia.

\section{RESEARCH LIMITATIONS}

Based on the research that has been done, there are several limitations in this study, namely the scope of research is limited in Denpasar City, so the results of this study cannot be generalized to other consumers for a wider area. Research is only on Bank Negara Indonesia internet banking applications, not on banking products in general or comparing Bank Negara Indonesia internet banking applications with other banks. The research data is taken at a certain time (cross section), it is hoped that in the future it can use time series data or research with longitudinal data to produce better research

\section{CONCLUSION AND SUGGESTIONS}

Based on the results of the research and discussion that have been conducted, some conclusions can be drawn, namely the perception of ease of use has a positive and significant influence on the perception of the benefits of Bank Negara Indonesia internet banking. This positive effect means that if customer's perception of the facilities formed better, the perception of the benefits of using Bank Negara Indonesia internet banking in Denpasar City will be more confident. Perception of ease of use has a positive and significant effect on the attitude to use the Bank Negara Indonesia internet banking. This positive influence means that the better the perception of the ease of use of customers about the facilities formed, the more confident the attitude of customers in using Bank Negara Indonesia internet banking in Denpasar City. Benefit perception has a positive and significant effect on the attitude to use Bank Negara Indonesia internet banking. This positive influence means that the better the perception of customer benefits about the facilities formed, the more confident the attitude of customers in using Bank Negara Indonesia internet banking in Denpasar City. The attitude to use has a positive and significant effect on the intention to use 
Bank Negara Indonesia internet banking. This positive influence means that the better the attitude to use customers is formed, the more confident the customers will be in using Bank Negara Indonesia internet banking in Denpasar City. Benefit perception has a positive and significant effect on the intention to use Bank Negara Indonesia internet banking. This positive influence means that the better perceptions of customer benefits are formed, the more confident the intentions of customers in using Bank Negara Indonesia internet banking in Denpasar City. Perception of ease of use has a positive and significant effect on the intention to use Bank Negara Indonesia internet banking. This positive influence implies that the better the perceived ease of use of the customer is formed, the more confident the intention of the customer in using Bank Negara Indonesia internet banking in Denpasar City. Trust has a positive and significant effect on the attitude to use Bank Negara Indonesia internet banking. This positive influence means that if the customer confidence formed better, the attitude of customers in using Bank Negara Indonesia internet banking in Denpasar City will be more confident. Trust has a positive and significant effect on the intention to use Bank Negara Indonesia internet banking. This positive influence means that if the customer confidence formed better, the more confident the intention of the customer in using Bank Negara Indonesia internet banking in Denpasar City.

Based on the results of the research, discussion, and conclusions that have been made, a number of suggestions can be drawn, namely for the company, BNI should continue to innovate in providing easy use of customers, add features that provide benefits for BNI customers, maintain the security of customer databases so as to make customer trust so that this will continue to increase the customer's intention to use BNI internet banking. Based on the results of the analysis on the characteristics of respondents, it is better for companies to prioritize marketing strategies for consumers in the age range of 18-28 years, female, bachelor's degree, and private employees. The advice that can be given is based on the respondent's answer to each variable, that is, it is better if the company Bank Negara Indonesia is more active in providing education to customers regarding the ease of using Bank Negara Indonesia interet banking. This can be done by means of education by opening stands at major activities. This step is done so that customers can more easily understand the features in internet banking and how to use them. It is better for the company Bank Negara Indonesia to be more active in providing understanding to customers about the benefits of Bank Negara Indonesia internet banking. This can be done by making a standing banner containing the benefits of internet banking at the office of Bank Negara Indonesia. This step is taken so that customers will easily obtain information about the benefits of Bank Negara Indonesia internet banking. It is better for Bank Negara Indonesia companies to be more active in educating about internet banking to make a positive attitude in using Bank Negara Indonesia internet banking. This can be done with the role of customer service to provide information and education about Bank Negara Indonesia internet banking so that customers have a positive attitude to use Bank Negara Indonesia internet banking. This step was taken so that customers have a positive attitude to use Bank Negara Indonesia internet banking. It is better for Bank Negara Indonesia companies to always maintain confidentiality and commitment so that Bank Negara Indonesia internet banking can be trusted by customers. This can be done by maintaining the security of Bank Negara Indonesia's internet banking transactions and maintaining the customer database. This step was taken so that the trust of Bank Negara Indonesia customers in using Bank Negara Indonesia banking internet banking. For further research, you should add indicators that are related to these variables and adapted to the conditions of the company and the intended respondent. In addition, further research should consider the characteristics of the sample by using clusters such as income, age, education so that the results of the study will be more specialized.

\section{REFERENCES}

1. Abeka, S. O. 2012. Perceived Usefulness, Ease of Use, Organizational and Bank Support As Determinants of Adoption of Internet Banking in East Africa, Vol. 2, No. 10, pp. 97-112. 
2. Ajam, A. S., and Nor, K. M. 2013. Influencing Factors on Behavioral Intention to Adopt Internet Banking Service, World Applied Sciences Journal, Vol. 22, No. 11, pp. 16521656.

3. Akinyemi, I. O., Asani, E. O., and Adigun, A.A. 2013. An Investigation of Users' Acceptance and Satisfaction of E-Banking System as a Panacea towards a Cashless Economy in Nigeria, Journal of Emerging Trends in Computing and Information Sciences, Vol. 4, No. 12, pp. 954-963.

4. Alsajjan, B. A., and Dennis. C. 2006. The Impact of Trust on Acceptance of Online Banking, European Association of Education and Research in Commercial Distribution, pp. 1-19.

5. Al-Somali, S. A., Gholami, R., and Clegg, B. 2009. An investigation into the acceptance of online banking in Saudi Arabia, Society of Interdisciplinary Business Research, Vol 2(2), pp. 578-601.

6. Ayo, K. C., Adewoye, O. J., and Oni, A.A. 2010. The State of e-Banking Implementation in Nigeria: A Post-Consolidation Review, Journal of Emerging Trends in Economics and Management Sciences, Vol 1(1), pp. 37-45.

7. Chang, J. L., Lieu, P. T., Liang, J. H., Liu, H. T., and Wong, S. L. 2011. Factors influencing technology acceptance decisions, African Journal of Business Management, Vol.5 (7), pp. 2901-2909.

8. Cheng, T. C., Lam, D. Y., and Yeung A. C. 2006. Adoption of Internet Banking: An Empirical Study in Hong Kong, Journal Decision Support Systems, Volume 42 issue 3, pp. 1558-1572.

9. Christiyanti, M., and Medyawati, H. 2010. Analysis Technology Acceptance Model (TAM) On Application E-Banking (Empirical Study Of Bank Customers In Bekasi), Und ergraduate Program, Economy Faculty.

10. Davis, F. D. 1989. Perceived Usefulness, Perceived Ease of Use, and User Acceptance of Information Technology, MIS Quarterly, Vol. 13, No. 3, pp. 319-340.

11. Ferdinand, A. 2002, Structural Equation Modelling dalam Penelitian Manajeme. Semarang: Badan Penerbit Universitas Diponogoro.

12. Hong, J. L. and Winstion, T. L. 2007. International E-Banking: ICT Investments and the Basel Accord. Journal of Comparative, Int.Management, Vol. 10, No. 1.

13. Islam, A. F. 2011. Viability Of The Extended Technology Acceptance Model: An Empirical Study, Journal of ICT, Vol. 10, pp. 85-98.

14. Jayasingh, S., and Eze, U. C. 2010. The Role of Moderating Factors in Mobile Coupon Adoption: An Extended TAM Perspective, IBIMA Publishing, pp.1-13.

15. Lule, I., Omwansa, T. K., and Waema, T. M. 2012. Application of Technology Acceptance Model (TAM) in M-Banking Adoption in Kenya, International Journal of Computing and ICT Research, Vol. 6 Issue 1, pp 31-43.

16. Mayasari, F., Kurniawati, E. P., and Nugroho, P. I. 2011. Anteseden and Konsekuen Sikap Nasabah Dalam Menggunakan Internet Banking Dengan Menggunakan Kerangka Technology Acceptance Model (Tam) (Survey Pada Pengguna Klikbca), Seminar Nasional Teknologi Informasi \& Komunikasi Terapan.

17. Medyawati, H., Christiyanti, M., and Yunanto, M. 2011. The Influence of Computer Self Efficacy, Computer Experience and Interface Design to Acceptance of Electronic Banking: Empirical Study of Bank Customers in Bekasi City, International Journal of eEducation, e-Business, e-Management and e-Learning, Vol. 1, No. 4, pp. 305-310.

18. Mohan, H., Ahmad, N., Kong, Q. C., Yew, C. T., Liew, J., and Mat, N. K. 2013. Determinants of the Internet Banking Intention in Malaysia, American Journal of Economics, Vol. 3, No. 3, pp. 149-152.

19. Njuguna, P. K., Ritho, C., Olweny, T., and Wanderi, M. P. 2012. Internet Banking Adoption in Kenya: The Case of Nairobi County, International Journal of Business and Social Science,Vol. 3, No. 18, pp. 246-252.

20. Park, S. Y. 2009. An Analysis of the Technology Acceptance Model in Understanding University Students' Behavioral intention e-Learning. Educational Technology \& Society, Vol 12, pp.150-162. 
21. Rahmawaty, A. 2013. Model Perilaku Penerimaan Internet Banking Di Bank Syari'ah: Peran Motivasi Spiritual, Annual International Conference on Islamic Studies, pp. 17841807.

22. Raman, A. 2011. University Management Information System (UMIS) Acceptance among University Student: Applying the Extended Technology Acceptance Model (ETAM), Journal of Studies in Education, Vol 1, No. 1, pp. 1-15.

23. Rigopoulos, G., and Askounis, D. 2007. A TAM Framework to Evaluate Users' Perception towards Online Electronic Payments, Journal of Internet Banking and Commerce, Vol. 12, No. 3, pp. 1-6.

24. Safeena, R., Date, H., Hundewale, N., and Kammani, A. 2011. Combination of TAM and TPB in Internet Banking Adoption, International Journal of Computer Theory and Engineering, Vol. 5, No. 1, pp. 146-150.

25. Sheikhi, Z., 2012. Study the Adoption of Electronic Banking Levels on the basis of Technology Acceptance Model (TAM), Journal of Basic and Applied Scientific Research, Vol 2, No 10, pp. 10726-10730.

26. Shroff, R. H., Deneen, C. C., Eugenia, M. 2011. Analysis of the technology acceptance model in examining students' behavioural niat untuk menggunakan an eportfolio system, Australasian Journal of Educational Technology, Vol. 27(4), pp. 600-618.

27. Site BNI. http://www.bni.co.id/ (diakses tanggal 16 Januari 2013 pukul 09:21).

28. Sugiyono. 2013. Metode Penelitian Kuantitatif Kualitatif and R \& D, Edisi 18. Bandung Alfabeta. p. 11-91.

29. Tan, P. J., Potamites, P. R., and Chi, L. W. 2012. Applying the TAM to understand the factors affecting use of online banking in the Pescadores, ARPN Journal of Science and Technology, Vol. 2, No. 11, pp. 1022-1028.

30. Tingari, W.M., and Abdelrahman, A.B. 2012. Acceptance of Banking Technology in Sudan: An Analytical Study, Research and Marketing, pp. 443-438.

31. Tjini, S. S., and Baridwan, Z. 2013. Pengaruh Kepercayaan, Persepsi Kegunaan, Persepsi Kemudahan, and Persepsi Kenyamanan Terhadap Minat Penggunaan Sistem Internet Banking, jimfeb.ub.ac.id, pp. 1-21.

32. Trisetyanto, T., and Mudiantono, H. 2011. Analisis Pengaruh Trust and Mutu E-Banking Terhadap Minat Bertansaksi Ulang Secara Online, eprints.undip.ac.id, pp. 1-27.

33. Venkatesh, V., and Bala, H. 2008. Technology Acceptance Model 3 and a Research Agenda on Interventions, Journal compilation Decision Sciences Institute, Vol. 39, No. 2, pp. 273-315.

34. Wang, W., and Benbasat, I. 2005. Trust in and Adoption of Online Recommendation Agents, Journal of the Association for Information Systems, Vol. 6 No.3, pp.72-101. 